https://doi.org/10.52240/1857-2367.2020.2(21).26

\title{
CONTRIBUȚII LA STUDIUL PRODUCTIVITĂȚII ȘI CALITĂȚII UNOR PAJIȘTI DIN PARCUL NAȚIONAL ORHEI
}

\author{
Aliona MIRON, Victor ȚîTTEI, Alexandru TELEUȚĂ, Alina PAVLIUC \\ Grădina Botanică Națională (Institut) „Al. Ciubotaru”, \\ Chişinău, Republica Moldova
}

\begin{abstract}
The paper presents data on the production and biochemical composition of hay of some types of grasslands in Orhei National Park in the conditions of 2020 year.

Key words: grasslands, Orhei National Park, production, biochemical composition pajiști.
\end{abstract}

Actualmente, în Republica Moldova se atestă lipsa unor studii și date statistice despre productivitatea și calitatea pajiștilor permanente. Astfel de date, în special cele cu privire la suprafața și producția pe tipuri de pajiști, conținutul de nutrienți, productivitatea şi calitatea pajiştilor ca răspuns la schimbările climatice, sunt foarte importante pentru calcularea unor indicatori pentru pajiști (de ex. stocul de carbon, emisiile/sechestrările de gaze cu efect de seră) și elaborarea politicilor în domeniul agriculturii și mediului.

Cercetări privind producția de fân și cantitatea de nutrienți au fost inițiate în anul 2020 în cadrul proiectului de cercetare și inovare 20.80009.7007.01 „Evaluarea vegetaţiei spontane din Republica Moldova pentru conservarea şi utilizarea durabilă a diversităţii plantelor şi resurselor genetice vegetale în contextul adaptării la schimbările climatice". Ca obiect de studiu au servit câteva tipuri de pajişti permanente din Parcul Naţional Orhei (comunele Ivancea și Puțintei din raionul Orhei) amplasate în lunci sau pe versanți, utilizate ca fânețe, nefertilizate.

Producția de fân a fost calculată în baza unei recolte de iarbă (recolta a doua nu fost realizată din cauza secetei din anul 2020). Din fiecare sector de pajiște au fost prelevate probe de iarbă de pe suprafețe de probă de $1 \mathrm{~m}^{2}$ în 3 repetiții, cântărindu-se masa verde recoltată. Probele au fost uscate în condiții de laborator în aer liber și din nou cântărite pentru calcularea substanței uscate. După dehidratarea completă $\left(\right.$ la $\left.105^{\circ} \mathrm{C}\right)$, din cele 3 probe recoltate în fiecare sector au fost luate probe medii pentru analize biochimice. Rezultatele măsurărilor și analizelor sunt prezentate în Tabelul 1.

Analiza rezultatelor obținute pe tipuri de vegetație și tipuri de relief denotă următoarele aspecte:

1. Producția pajiștilor de luncă variază între 4,7-4,9 t/ha fân (pajiști de Elytrigia repens $-4,7$ t/ha fân; pajiști de Lolium perenne $-4,9$ t/ha fân), ceea ce încadrează aceste pajiști în categoria pajiștilor cu productivitate foarte mare [1].

2. Producția pajiștilor amplasate pe versant variază între 1,7-2,7 t/ha fân (pajiști de Festuca valesiaca - 1,7-2,7 t/ha fân; pajiști de Botriochloa ischaemum - 2,3 t/ha fân), ceea ce încadrează aceste pajiști în categoria pajiștilor cu productivitate mijlocie [1].

3. Fânul recoltat din pajiștile de pe versant are o asigurare mai bună cu proteină și energie metabolizantă comparativ cu fânul din pajiștile de luncă, ceea ce denotă că atât valoarea furajeră, cât și cea energetică sunt determinate de diversitatea speciilor de plante și abundența mai mare a leguminoaselor pe pajiștile respective. 
Tabelul 1. Producția și compoziția biochimică a fânului în condițiile anului 2020

\begin{tabular}{|c|c|c|c|c|c|c|c|c|c|c|c|}
\hline 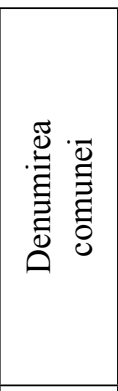 & $\mid \begin{array}{c}\text { Denumirea } \\
\text { sectorului } \\
\text { de pajiște }\end{array}$ & $\begin{array}{l}\text { Tipul de } \\
\text { pajiște }\end{array}$ & $\begin{array}{l}\text { Produc- } \\
\text { tia } \\
\text { de fân, } \\
\text { t/ha }\end{array}$ & $\begin{array}{c}\text { Prote- } \\
\text { ină } \\
\text { brută, } \\
\%\end{array}$ & $\begin{array}{c}\text { Grăsi } \\
\text { me } \\
\text { brută, } \\
\%\end{array}$ & $\begin{array}{c}\text { Celu- } \\
\text { loză } \\
\text { brută, } \\
\%\end{array}$ & $\begin{array}{c}\text { Sub- } \\
\text { stante } \\
\text { extrac- } \\
\text { tive } \\
\text { neazo- } \\
\text { tate, } \\
\%\end{array}$ & $\mid$ & 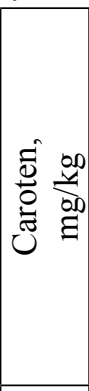 & $\begin{array}{c}\text { Ener- } \\
\text { gie } \\
\text { me- } \\
\text { taboli- } \\
\text { zantă } \\
\text { pent- } \\
\text { ru bo- } \\
\text { vine, } \\
\mathrm{MJ} / \mathrm{kg}\end{array}$ & $\begin{array}{c}\text { En- } \\
\text { ergie } \\
\text { me- } \\
\text { taboli- } \\
\text { zantă } \\
\text { pentru } \\
\text { oi, } \\
\mathrm{MJ} / \mathrm{kg}\end{array}$ \\
\hline Ivancea & Tur Baza & \begin{tabular}{|l|}
$\begin{array}{l}\text { Lolium } \\
\text { perenne }\end{array}$ \\
\end{tabular} & 4,9 & 10,26 & 1,69 & 32,01 & 46,94 & $9,10 \mid$ & 6,60 & 7,30 & 7,67 \\
\hline Puțintei & $\begin{array}{c}\text { Opt } \\
\text { Martie }\end{array}$ & $\begin{array}{l}\text { Elytrigia } \\
\text { repens }\end{array}$ & 4,7 & 6,62 & 2,47 & 30,78 & 53,02 & 7,12 & 4,40 & 7,33 & 7,66 \\
\hline Puțintei & $\begin{array}{c}\text { Hîrtoape } \\
\text { Lagăr }\end{array}$ & $\begin{array}{l}\text { Botriochloa } \\
\text { ischaemum }\end{array}$ & 2,3 & 10,16 & 2,54 & 31,66 & 47,33 & 8,32 & 32,17 & 7,46 & 7,85 \\
\hline Ivancea & $\begin{array}{l}\text { Lângă } \\
\text { Satul } \\
\text { Ivancea }\end{array}$ & $\begin{array}{l}\text { Festuca } \\
\text { valesiaca }\end{array}$ & 2,0 & 9,35 & 3,14 & 31,92 & 47,89 & 7,71 & 11,35 & 7,50 & 7,91 \\
\hline Ivancea & La Iaz & \begin{tabular}{|l|} 
Festuca \\
valesiaca
\end{tabular} & 2,7 & $\mathbf{9 , 5 8}$ & 2,60 & 31,27 & 49,03 & 7,52 & 10,83 & 7,53 & 7,94 \\
\hline Puțintei & $\begin{array}{c}\text { Hîrtoape } \\
\text { Lagăr }\end{array}$ & $\begin{array}{l}\text { Festuca } \\
\text { valesiaca }\end{array}$ & 1,7 & 12,20 & 2,98 & 29,92 & 47,38 & $|7,52|$ & 24,65 & 7,97 & 8,38 \\
\hline
\end{tabular}

\section{BIBLIOGRAFIE SELECTIVĂ}

1. Bărbulescu C., Burcea P. Lucrări practice la păşuni și fânețe. București, Ed. Agro-silvică, 1956, p. 81. 